\title{
The Effect of Bathing Length Time to Axillary Temperature and Dry Heat Loss on Newborns; A Comparative Analysis
}

\author{
Hotma Sauhur Hutagaol* \\ Midwifery Study Program of Padangsidimpuan, Poltekkes Kemenkes Medan, Sigulang, Padangsidimpuan, Indonesia.
}

Received: February 27, 2021; Revised: June 21, 2021; Accepted: August 24, 2021

\begin{abstract}
Hypothermia often occurs at the transition stage of a newborn. Transition stage is a critical stage for newborns to survive. Bathing with improper techniques can cause cold and heat loss even hypothermia in newborns. The purpose of this study was to analyzed the comparison of the length time of first time bathing for normal newborns with axillary temperature and dry heat loss with seven minutes and thirteen minutes respectively. Bathing was held on the six hours postbirth. This study was a quasi-experimental study with a pre and post test group design. Data were analyzed using Mann-Whitney test, and $\mathrm{p}$ value $<0.05$ was considered statistically significant. Sample size were two groups with 24 newborns each. This research showed that the average of axillary temperature of newborn in intervention group A (IGA, 7 Min) was higher than in intervention group B (IGB, 13 Min), and statistically with Mann-whitney test significant with p value $<0.05$. The average of dry heat loss (conductive, convective and radiative heat loss) was higher in intervention group A (IGA, 7 Min) than in intervention group B (IGB, 13 Min) but statistically with Mann-whitney test not significant with p value $>0.05$.
\end{abstract}

Keywords: Bathing, Newborn, Temperature, Dry Heat Loss

\section{Introduction}

Bathing a newborn for the first time with improper length of bath time and techniques can cause cold and heat loss to the newborn, even hypothermia. For this reason, based on WHO recommendations, bathing should be delayed for 24 hours after the newborn is born, or 48 hours for better and effective preserving of the body temperature, and if it is not possible due to cultural reasons or customs in an area, bathing should be delayed until 6 hours after the baby is born, with the condition that the baby's body temperature is normal around $36.5^{\circ} \mathrm{C}-37.5^{\circ} \mathrm{C}$. Appropriate clothing to maintain temperature stability in newborns is also recommended, which is 1-2 layers more than adults and wearing a hat. But the literature about the length time of first time bathing newborns is rather limite (OLCHC, 2015; WHO, 2017; Chamberlain et al., 2019; Duygu et al., 2019; Susan et al., 2019).

Hypothermia tends to occur during the transition period in newborns. Adaptation to extra-uterine life is a very critical period for the baby in an effort to survive, newborn babies must adapt the sudden change in thermal homeostatis to life outside the uterus whose temperature is much cooler when compared to temperatures in the mother's womb that are relatively warmer around $37^{\circ} \mathrm{C}$. With a normal room temperature of $25^{\circ} \mathrm{C}-27^{\circ} \mathrm{C}$ means there is a decrease of around $10^{\circ} \mathrm{C}$. Maintenance of thermal homeostasis is crucial for the success of postnatal transition, even for the aterm and healthy newborn baby. Thus, the control of the core and the surface body temperature needs to be managed carefully to prevent heat loss (WHO, 2013; Morton et al., 2016; Perlman and Kjaer, 2016; Lubkowska et al., 2019).

Newborn lose heat four times more than adults, which results in a decrease in temperature. Newborns can have a temperature drop of $3-4^{0} \mathrm{C}$ in the first 30 minutes of labor. And their skin temperature will drop by about $0.3^{0} \mathrm{C}$ if placed in a room with a temperature of $20-25^{\circ} \mathrm{C}$. The decrease in temperature is caused by heat loss (conduction, convection, evaporation and radiation). Loss of heat by conduction, convection and radiation is also called dry heat loss, whereas heat loss by evaporation is also called wet heat loss. With the infant's immature thermoregulation ability to produce heat, the baby is very susceptible to the experience of hypothermia (Kliegman, 2012; Namnabati et al., 2017; Khaled and Mohammed, 2019).

Therefore, essential care is needed in newborns to prevent complications and can save the lives of babies such as drying the newborn's body immediately, breastfeeding and delaying bathing the baby for 6 hours after delivery or after the body temperature of the newborn is normal $36.5^{\circ} \mathrm{C}-37.5^{\circ} \mathrm{C}$ (Bergstrom et al., 2000; Heinig, 2001; Moore et al., 2012; Farhana et al., 2013; WHO, 2013; Lund, 2016).

Association of Women's Health, Obstetrics and Neonatal Nurses recommends delaying bathing the baby for up to 8 hours of labor because the body temperature of the newborn is stable after 2-4 hours of labor. Delaying bathing the newborn when the body temperature is stable will help the baby go through the transition period, reducing the incidence of hypoglycemia and hypothermia (AWHONN, 2015).

\footnotetext{
*Corresponding author e-mail: rutandsteven@gmail.com..
} 
This contradicts the results of research that bathing a newborn in one hour postbirth will maintain newborn body temperature if the newborn has a normal body temperature (Karen and Rita, 2000; Lund, 2014).

World Health Organization recommends bathing babies with a water temperature of $38^{\circ} \mathrm{C}$ but Puspita in her study obtained a safe bath water temperature for bathing a baby 6 hours of labor was $35^{\circ} \mathrm{C}$. She also got the result that bathing a newborn was better done in the afternoon than in the morning (Puspita et al., 2007).

The data above shows that the implementation of bathing a newborn still needs more research to obtain better benefits, so that it can prevent hypothermia and improve the health of newborns, because of the greatly benefits of bathing when done properly.

Previous studies found that after bathing newborns for 7.6 minutes length, at one hour, two hours and 4 hours of labor, there was no difference in axillary temperature on 10, 20, 60 minutes each. But it has not been seen how much heat loss is in newborns after being bathed (Karen and Rita, 2000).

Because the pilot study revealed no significant difference in postbath temperatures between newborns bathed at one hour and two hours of age with the same length time of bath, the purpose of the current study was to see if the length time of bathing could be done even longer to see the difference change of axillary temperature and the dry heat loss of the newborn after bathed at 24 hours of birth. It was hypothesized that there would be a significant difference in postbath temperatures between newborns length time of bath at 7 minutes and 13 minutes; the purpose of the current study was to see if the length time of bath could be done even longer at the transition period in newborns.

Therefore, this study aimed to analyze the comparison of newborns bath length of time to axillary temperature and dry heat loss.

\section{Materials and Methods}

The Health Research Ethics Committee of Polytechnic Health Ministry of Health Medan Indonesia approved the current study (approval number 367/KEPK POLTEKKES KEMENKES MEDAN/2019). The objectives and methodologies were explained to all participants, and verbal consent had been taken. The research was conducted for six months. The population in this study were all newborns in Padangsidimpuan City Hospital. Sample was all populations that meet the inclusion and exclusion criteria. The sample chosen for the study was newborn who fullfilled inclusion criteria; normal newborn, six hours postbirth, normal body temperature of $36.5^{\circ} \mathrm{C}-$ $37.5^{\circ} \mathrm{C}$. Exclusion criteria were hyperthermia and congenital abormalities; there was meconium in the amniotic fluid with head presentation.

This research was a quasi-experiment study with a pre and post control group design, and the aim was to analyze the comparison of the length of bathing time for newborns with body temperature and heat loss. The length time of bathing was seven minutes in intervention group A (IGA) and 13 minutes in intervention group B (IBG) respectively. The length of bath time is calculated starting from preparing toiletries then bathing the baby and finally wearing clothes. The design approach in this study can be described as follows:

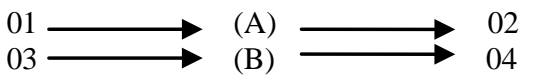

01 IGA before bathing; 02 IGA after bathing 03 IGB before bathing; 04 IGB after bathing

(A) Intervention group A bathing in 7 minutes; (B) Intervention group $\mathrm{B}$ bathing in 13 minutes

Operational Definitions of Independent Variables and Dependent Variables:

a) Newborn Bathing

Defenition : Bathing newborn at six hours after birth.

How to measure : Bathing newborns in 7 minutes and 13 minutes respectively.

Measuring instrument : Newborn Bathing Guideline from Module of Text Book Practice of Midwifery Care of Neonates, Babies, Toddler and Children, Indonesian Health Ministry 2016.

Measuring results : If the bath duration is 7 minutes then it is given a value of 1 , and if the bath duration is 13 minutes then it is given a value of 0 .

Measuring scale : nominal

b) Temperature

Defenition : Newborn Axilla temperature

How to measure : measuring axilla temperature before and after bathed

Measuring instrumen : digital thermometer

Measure results : temperature in ${ }^{0} \mathrm{C}$

Measuring scale : interval

c) Dry Heat Loss

Defenition : Dry heat loss in newborn (convective, radiative and conductive heat loss).

How to measure : using equation (Gabriel, 1996; Celcar, 2013)

Measuring Scale : Equality (Gabriel, 1996, Celcar, 2013)

1) Convective Heat Loss:

$\mathrm{Jq}$ convective $=8,3 \mathrm{~V}^{0,5}\left(\mathrm{~T}_{\mathrm{s}}-\mathrm{T}_{\mathrm{a}}\right)$

$\mathrm{Jq}$ convective $=$ convective heat loss between newborn skin and environment $(\mathrm{J})$

$\mathrm{V}=$ air flow velocity $(\mathrm{m} / \mathrm{s})$

$8,3=$ a constant where a person stands facing the blowing air

Ts = skin temperature $\left({ }^{0} \mathrm{C}\right)$

Equation Mean skin temperature:

$0,07 \mathrm{~T}_{\text {Forehead }}+0,175 \mathrm{~T}_{\text {Trunk }}+0,175 \mathrm{~T}_{\text {Chest }}+0,07 \mathrm{~T}_{\text {Arm }}+$ $0,07 \mathrm{~T}_{\text {Shoulder }}+0,05 \mathrm{~T}_{\text {Hand }}+0,2 \mathrm{~T}_{\text {Calf }}+0,19 \mathrm{~T}_{\text {thigh }}$

$\mathrm{Ta}=$ air temperature $\left({ }^{0} \mathrm{C}\right)$

2) Radiative Heat Loss :

Jq radiative $=\mathrm{e} \sigma \operatorname{Ar}\left(\mathrm{T}_{\mathrm{s}}{ }^{4}-\mathrm{T}_{\mathrm{w}}{ }^{4}\right)$

$\mathrm{Jq}_{\text {radiative }}=$ radiative heat loss $(\mathrm{J})$

$\mathrm{Ar}=$ the efective surface area of the body that releases radiation (Du bois) which is $\mathrm{W}^{0.5378} \times \mathrm{L}^{0.3964} \times 0.024265$

(weight in $\mathrm{kg}(\mathrm{W})$, and length in $\mathrm{cm}(\mathrm{L})$. (Haycock, 1978)

$E=$ skin surface emissivity, 0,99 (Alexandra, 2000)

$\sigma=$ Stefan - Boltzmann constant $\left(5,67 \times 10^{-8} \mathrm{~W} / \mathrm{m}^{2} \mathrm{~K}^{4}\right)$

$\mathrm{Ts}=$ skin temperature in absolute degree $(\mathrm{K})$

$\mathrm{Tw}=$ wall temperature in absolute degree $(\mathrm{K})$

3) Conductive Heat Loss 


$$
\mathrm{Jq}_{\text {conductive }}=\frac{\text { kes ka }}{\text { Kest ka }} \frac{\left(T_{z}-T_{1}\right)}{\Delta X}
$$

. Jq C $\mathrm{C}_{\text {onductive }}=$ conductive heat loss $(\mathrm{J})$; ks = skin conductivity coefficient $\left(0,2 \mathrm{~J} / \mathrm{sm}^{0} \mathrm{C}\right) ; \mathrm{Ka}=$ air conductivity coefficient $(0,023$ $\left.\mathrm{J} / \mathrm{sm}^{0} \mathrm{C}\right) ; \mathrm{T}_{2}-\mathrm{T}_{1}=$ different temperature between air and skin

$\left({ }^{0} \mathrm{C}\right) ; \Lambda \mathrm{x}=$ the distance between air and skin

4) Total Dry Heat Loss

$$
\mathrm{J}_{\text {total }}=\mathrm{J}_{\mathrm{q} \text { convective }}+\mathrm{J}_{\mathrm{q} \text { konduksi }}+\mathrm{J}_{\mathrm{q} \text { radiasi }}
$$

Measuring Instrument: Digital Infra red Thermometer, anemometer, nomogram duBois, body length measuring board, baby weight scales.

Measuring Result: Total Dry Heat Loss in J (joule).

Measuring Scale : Interval.

a. Normal newborn is newborn with 2500 - 4000 gr, body length of $44-53 \mathrm{~cm}$, gestation 37 - 42 weeks, APGAR Score 7-10.

The number of samples taken must be the same between the two groups so that the results of the study are more significant.

The sample Equations used was Sastroasmoro formula (Sastroasmoro, 2011):

$$
n_{1}=n_{2}=2\left[\frac{(z \alpha+z \beta) S}{x_{1}-x_{2}}\right]
$$

$\mathrm{z} \alpha=1,96 ; \mathrm{z} \beta=1,282 ; \mathrm{S}=$ Standar deviation of the two groups $1,1^{0} \mathrm{C} ; \mathrm{X}_{1}-\mathrm{X}_{2}=$ Clinical differences $=1^{0} \mathrm{C}$

$$
\mathrm{n}_{1}=\mathrm{n}_{2}=2[(1,96+1,282) 1,1]^{2}
$$

$\mathrm{n}_{1}=\mathrm{n}_{2}=24$

a) Measurements taken in both groups of newborns were heart rate, axillary temperature, skin temperature, air temperature, wall temperature and wind speed before and after bathing. Measurements of weight and body length were also taken.

b) Room temperature set arround $27^{\circ} \mathrm{C}-30^{\circ} \mathrm{C}$.

c) Water temperature from $37^{\circ} \mathrm{C}-38,5^{\circ} \mathrm{C}$.

d) Time of bathing about $03.00 \mathrm{pm}$.

e) Both of groups will be given clothes with the same material which is 1 layer of cloth and 1 hat.

f) After bathing, babies were immediately measured for skin and body temperature (axillary temperature) and immediately breastfed to avoid cold.

g) The health workers who bathe the baby are two midwives who have been given counseling about hypothermia. The first midwife bathed the newborns in the intervention group A (IGA) while the second midwife bathed the newborns in the intervention group B (IGB).

h) Then the differences between the pre-test and post-test in each intervention group were examined and the differences were analyzed

Data were analyzed by Mann-Whitney test to compare pre-test and post test data.

\section{Results}

The study was conducted in the city of Padangsidimpuan from March 2019 to October 2019. After observing, 48 newborns were found who met the inclusion criteria. 24 newborns will be bathed for seven minutes and will be called the Intervention A (IGA) group and 24 newborns will be bathed for 13 minutes and will be called the intervention group B (IGB). The average room temperature was $30.3\left({ }^{\circ} \mathrm{C}\right)$, water temperature was $38.3\left(^{\circ}\right.$ C) and air flow velocity in the room was $0.1 \mathrm{~m} / \mathrm{s}$. table.

The results of this study can be seen in the following

Table 1: Characteristics of Respondents.

\begin{tabular}{llll}
\hline $\begin{array}{l}\text { Characteristics of } \\
\text { Respondents }\end{array}$ & $\begin{array}{l}\text { Intervention } \\
\text { Group A } \\
\text { Mean } \pm \text { SD }\end{array}$ & $\begin{array}{l}\text { Intervention } \\
\text { Group B } \\
\text { Mean } \pm \text { SD }\end{array}$ & Sig \\
\hline $\begin{array}{l}\text { Body Weight } \\
\text { (BW) Kg }\end{array}$ & $3216 \pm 286$ & $3100 \pm 408$ & $p>0.05$ \\
$\begin{array}{l}\text { Body Surface Area } \\
\text { (BSA) }\end{array}$ & $0.21 \pm 0.01$ & $0.20 \pm 0.01$ & $p>0.05$ \\
$\begin{array}{l}\text { Axillary } \\
\text { Temperatur (AT) } \\
\left({ }^{0} \mathrm{C}\right)\end{array}$ & $36.98 \pm 0.42$ & $36.99 \pm 0.36$ & $p>0.05$ \\
$\begin{array}{l}\text { Skin Temperature } \\
\text { (ST) }\left({ }^{0} \mathrm{C}\right)\end{array}$ & $36.72 \pm 0.44$ & $36.72 \pm 0.51$ & $p>0.05$ \\
\hline Source : Primary data, 2019. & & \\
\hline
\end{tabular}

Table 1 showed the characteristics of respondents. Based on its characteristics, the mean respondent's body weight of respondents was $3216 \pm 286$ gr for IGA and $3100 \pm 408$ for IGB. The mean respondent's body surface area (BSA) was $0.21 \pm 0.01$ for IGA and $0.20 \pm 0.01$ for IGB. The mean respondent's systolic was $147,7 \pm 9,0$ $\mathrm{mmHg}$ for intervention group and 153,3 $\pm 10,1 \mathrm{mmHg}$ for the control group. The mean respondent's axillary temperature was $36.98 \pm 0.42{ }^{\circ} \mathrm{C}$ for IGA and $36.99 \pm 0.36$ ${ }^{0} \mathrm{C}$ for IGB. The mean respondent's skin temperature was $36.72 \pm 0.44{ }^{0} \mathrm{C}$ for IGA and $37.72 \pm 0.51{ }^{0} \mathrm{C}$ for IGB. Statistically with the Mann-Whitney technique, there was no significant difference between the two groups with a value of $\mathrm{p}>0.05$.

Table 2: The Comparison Between the Length Time of bathing

\begin{tabular}{|c|c|c|c|}
\hline \multicolumn{4}{|c|}{ Axillary Temperature } \\
\hline & $\begin{array}{l}\text { Mean } \pm \text { SD }\left({ }^{0} \mathrm{C}\right) \\
\text { Before The Bath }\end{array}$ & $\begin{array}{l}\text { Mean } \pm \mathrm{SD}\left({ }^{0} \mathrm{C}\right) \\
\text { after the bath }\end{array}$ & Sig \\
\hline IGA (7 Min) & $36.98 \pm 0.42$ & $36.32 \pm 0.49$ & 0.001 \\
\hline IGB (13 Min) & $36.99 \pm 0.36$ & $36.04 \pm 0.39$ & \\
\hline \multicolumn{4}{|c|}{ Difference in Axillary Temperature in Newborn after The Bathing } \\
\hline & $\begin{array}{l}\text { Mean } \pm \text { SD (0C) } \\
\text { After The Bath }\end{array}$ & Sig & \\
\hline IGA (7 Min) & $0.66 \pm 0.30$ & 0.001 & \\
\hline IGB (13 Min) & $0.95 \pm 0.31$ & & \\
\hline \multicolumn{4}{|c|}{ Dry Heat Loss in Newborn. } \\
\hline & $\begin{array}{l}\text { Mean } \pm \text { SD (J) } \\
\text { Dry Heat Loss }\end{array}$ & Sig & \\
\hline \multicolumn{4}{|l|}{ Conductive } \\
\hline Heat Loss & $11.14 \pm 2.48$ & 0.54 & \\
\hline IGA (7 Min) & $10.85 \pm$ & & \\
\hline IGB (13 Min) & 1.99 & & \\
\hline \multicolumn{4}{|l|}{ Convective } \\
\hline Heat Loss & $14.36 \pm 3.20$ & 0.54 & \\
\hline IGA (7 Min) & $14.00 \pm 2.56$ & & \\
\hline \multicolumn{4}{|l|}{ IGB (13 Min) } \\
\hline \multicolumn{4}{|l|}{ Radiative Heat } \\
\hline Loss & $7.26 \pm 1.50$ & 0.65 & \\
\hline IGA (7 Min) & $7.17 \pm 1.14$ & & \\
\hline \multicolumn{4}{|l|}{ IBG (13 Min) } \\
\hline \multicolumn{4}{|c|}{ Skin Temperature in Newborn } \\
\hline & $\begin{array}{l}\text { Mean } \pm \text { SD }\left({ }^{0} \mathrm{C}\right) \\
\text { After The Bath }\end{array}$ & Sig & \\
\hline IGA (7 Min) & $36.01 \pm 0.39$ & 0.001 & \\
\hline IGB (13 Min) & $35.87 \pm 0.36$ & & \\
\hline
\end{tabular}
on Average \pm SD to Axillary Temperature in Newborn, Difference in Axillary Temperature in Newborn after The Bathing, Dry heat Loss of Newborn and Skin Temperature of Newborn

Table 2 showed that the mean axillary temperature after being bathed for seven minutes in IGA decreased by 0.66 
\pm 0.30 . Statistically with the Wilcoxon test, there were significant differences with $\mathrm{p}$ value $<0.05$.

The mean axillary temperature after bathing for 13 minutes in the IGB decreased by $0.95 \pm 0.31$. Statistically with the Wilcoxon test there are significant differences with $\mathrm{p}$ value $<0.05$.

Table 2 also showed the mean difference in axillary temperature after being bathed 7 minutes in the IGA lower than in the IGB which was bathed for 13 minutes. The mean difference in axillary temperature in the IGA was $0.66 \pm 0.40$, and the average axillary temperature in the IGB was $0.95 \pm 0.31$. Statistically with the Mann-Whitney test, there were significant differences with $\mathrm{p}$ value 0.001 $(<0.05)$.

Table 2 also showed that the mean convective heat loss after being bathed for 7 minutes in the IGA was higher than in the IGB which was bathed for 13 minutes. The mean convective heat loss in the IGA was $14.36 \pm 3.20$, and the mean convective heat loss in the IGB was $14.00 \pm$ 2.56. Statistically with the Mann-Whitney technique, there was no significant difference with p value $>0.05$.

The mean radiative heat loss after being bathed for 7 minutes in the IGA was higher than in the IGB which was bathed for 13 minutes. The mean radiative heat loss in the IGA was $7.26 \pm 1.50$, and the mean radiative heat loss in the IGB was $7.17 \pm 1.14$. Statistically with the MannWhitney technique, there was no significant difference with $p$ value $>0.05$

Table 2 also showed that the mean skin temperature of newborns in the IGA after bathing for seven minutes is $36.01 \pm 0.39{ }^{\circ} \mathrm{C}$; the mean temperature of newborn skin in the IGB after being bathed for 13 minutes was $35.87 \pm$ $0.36{ }^{\circ} \mathrm{C}$. Statistically, there was no significant difference between Mann Whitney with p value> 0.05 .

\section{Discussion}

This study compared the axillary temperature and dry heat loss of newborns bathed in seven minutes and 13 minutes respectively for the first time. The findings showed significant statistical difference between both bathing length time in axillary temperature. The maximum variation in the pre- and postbath temperature averages were -0.6 and $-0.9^{\circ} \mathrm{C}$ respectively, in the IGA and IGB, indicating that the length of time for the first bath had a significant effect on the decrease in axillary temperature of newborns, but all of them experienced mild hypothermia. This might be due to the direct exposure of a newborn baby to a cold environment such as being put into warm water naked. For that, proper care is recommended after bathing a newborn baby, such as immediately wearing clothes and hats, and immediately handing over to the mother for immediate breastfeeding. On this study, almost all newborns in both intervention groups experienced axillary temperature recovery to be normal again after 15 minutes of breastfeeding by mother.

This study was in line with research that examined the comparison of conventional methods of bathing premature babies with the method of wrapping a baby in a bath or swaddled immersion bath which got the results of both treatment groups experienced a decrease in axillary temperature of the newborn; this study also got results that the axillary temperature of the newborn remains below normal or hypothermia after 20 minutes the baby is bathed.
The temperature of new infants is in the range of 36.0 $36.5^{\circ} \mathrm{C}$ or mild hypothermia (Alexandra et al., 2000; Freitas et al., 2018).

Gozen (2019) also found that there was significant difference in body temperature in newborns who were bathed at 48 hours. He also found that after 24 hours of delivery, there was a decrease in axillary temperature after bathing on the first day of the newborn, and recommended delaying bathing for up to 48 hours of labor (Gozen et al., 2019).

In line with Gozen's research (2019), it was also found that axillary temperature decreased after bathing on the first day of the baby. The same was obtained by experimental studies in Iran that compared axillary temperature in 50 premature newborns with the usual bathing method and the bathing method by being wrapped. The mean axillary temperature after 10 minutes of bathing with the wrapped method was higher than that of the baby group bathed by the conventional or conventional method (36.42 ${ }^{\circ} \mathrm{C}$ versus $35.96{ }^{\circ} \mathrm{C}$ ). The mean axillary temperature reduction was $0.59^{\circ} \mathrm{C}$ in the wrapped method and $0.08{ }^{\circ} \mathrm{C}$ in infants bathed by conventional methods, whereas in this study the mean decrease in axillary temperature in the IGA bathed for seven minutes was 0.66 $\pm 0.30^{\circ} \mathrm{C}$ lower when compared to the mean decrease in axillary body temperature in the IGB which was bathed for 13 minutes which was $0.95 \pm 0.31{ }^{\circ} \mathrm{C}$ (Edraki et al., 2014).

Clasen found no difference in axillary temperature of newborns who were bathed for 2 hours, 6 hours, 9 hours after delivery, and all newborns who were bathed at these three times experienced a decrease in axillary temperature (Clasen and Kellie, 2019).

Decreased axillary temperature in newborns after bathing can be related to the removal of vernix caseosa. The function of vernix caseosa, which prevents heat loss, no longer functions and a decrease in axillary temperature becomes unavoidable (Jhonson and Taylor, 2005; Thilo and Rossenberg, 2011; Sukesi et al., 2016; Turney et al, 2019).

According to this study, it states that newborns who bathed after six hours of labor had an axillary temperature in the mild hypothermia range after a 7 - 13 minutes bath. Therefore, it is recommended that the newborns bathe for less than 7-13 minutes.

Efforts to maintain a constant body temperature are very important in newborns with low thermoregulatory abilities. The use of energy by newborns to produce heat comes from thermoregulation without shivering, one of three adults' ability to produce heat through metabolism, shivering thermoregulation and non-shivering thermoregulation. The heat source of thermoregulation without chills in newborns comes from brown fat tissue that is stored from the age of 26-28 weeks of pregnancy and contributes to $10 \%$ of newborn body weight. Brown fat tissue is filled with blood vessels and is located mostly in the shoulder area, armpits, around the waist and adrenal glands. If the baby experiences a cold which will increase the increase in the work of the hormone nor adrenaline which will stimulate the breakdown of brown fat tissue to produce heat, unfortunately this brown fat tissue can no longer form. Body surface area is also one of the causes of babies experiencing heat loss, lack of muscle movement and also the ability to regulate blood flow through the skin. 
The lack of optimal circulation and respiratory system development is also a factor in the lack of thermoregulation in newborns. This ability will only develop in the first week of infancy (McHugh, 2008; Fraser and Cooper, 2009; WNHS, 2018; Lubkowska et al., 2019).

Newborns have not been able to maintain their own body temperature without protection from the outside, especially when placed in a cold environment that can reduce the core temperature around $0.2-1.0^{\circ} \mathrm{C}$ per minute and can eventually result in death. World Health Oorganization recommends maintaining body temperature as a main principle when providing care for newborns (WHO, 2012).

Some research results showed that after 15 minutes of birth the skin temperature of the newborn will drop to $4{ }^{\circ} \mathrm{C}$, after the first hour of birth the skin temperature can drop to around $33^{\circ} \mathrm{C}$ if placed in a room with a temperature of around $25^{\circ} \mathrm{C}$. After 15 minutes, the skin temperature can decrease around $2.5-3^{\circ} \mathrm{C}$, and in the first 15 minutes this attempt to produce heat by shivering does not occur in newborns (Lubkowska et al., 2019).

In this study, the average skin temperature of participants before bathing in the IGA was $36.72 \pm 0.44{ }^{\circ} \mathrm{C}$ and after bathing the skin temperature decreased by an average of $36.01 \pm 0.29^{\circ} \mathrm{C}$ while the mean temperature of newborns before bathing in the IGB was $36.72 \pm 0.51^{\circ} \mathrm{C}$ and after the bath also decreased by an average of $35.87 \pm$ $0.36^{\circ} \mathrm{C}$. After bathing for seven minutes there was a decrease in the average skin temperature of around $0.71^{\circ}$ $\mathrm{C}$ in the IGA, whereas in the IGB, there was a decrease in the average skin temperature of $0.9^{\circ} \mathrm{C}$ after bathing for 13 minutes. However, this wasn't statistically significant. If the body temperature changes to $10 \mathrm{oC}$, there will be a change of $10 \%$ from the metabolic rate and oxygen consumption. So by measuring the oxygen consumed by the body, we can estimate the energy or heat produced. If the IGA experienced a decrease in skin temperature after being bathed at around $0.71^{\circ} \mathrm{C}$, there would be a change of $7 \%$ from the metabolic rate and oxygen consumption. While in the IGB the skin temperature after being bathed was around $0.9^{\circ} \mathrm{C}$, therefore there will be a change of $9 \%$ of the metabolic rate and oxygen consumption. This certainly will aggravate the work of newborn metabolism and increase the need for oxygen consumption. If the decrease in body temperature continues without any effort to help prevent heat loss it will have an adverse effect on newborns. They'll have to depend on unrenewable brown adipose tissue to increase metabolism which will generate heat (Karlsson, 1996; Sherwood, 2012; Girsjesh and Shefali, 2019).

Heat loss in newborns can occur by conduction, convection, radiation called dry heat loss, and evaporation called wet heat loss. In the IGA and IGB groups, there was little difference in dry heat loss. However, IGA showed more signs of heat loss through conducting, convection, and radiation. There was also difference in skin temperature and axillary temperature, IGA showed lower decrease of skin temperature and axillary temperature. This situation may be influenced by several factors such as gender or maternal factors. These factors were not examined in this study, and are a weakness of this study; it is hoped that in the future further research will be conducted that will pay attention to the sex factors of newborns and maternal factors.

After being bathed, clothes and hats were immediately attached and newborns immediately given to mothers for breastfeeding for 15 minutes in both of intervention group in this study. Axillary temperature and skin temperature return to normal after that. Therefore, it was recommended that newborns be breastfed for 15 minutes after bathing.

\section{Conclusion}

The results indicate that bathing in 7 minutes or 13 minutes significantly differ regarding their effect on axilla temperature and skin temperature of healthy newborns for the first time. Dry heat loss was higher in newborns when bathing in 7 minutes compared to 13 minutes but not statistically significant. However, future studies addressing the suitable length time of bathing newborns are necessary, as well as studies investigating more indicators of the length time of bathing newborns such as the gender factor, the types of labour, and physiological indicators of stability.

\section{Acknowledgment}

The authors are grateful to all participants who contributed this study and to Poltekkes Kemenkes Medan who funded this study.

\section{Funding}

This study was funded by Poltekkes Kemenkes Medan.

\section{References}

Alexandra AK, Nelson RA, Bell ER and Cesar AE. 2000. Use of infrared thermographic calorimetry to determine energy expenditure in preterm infants. Am J Clin Nutr., 71:969. http//ajcn.nutrition.org.

AWHONN (Association of Women's Health, Obstetrics and Neonatal Nurses). 2015. Improving Newborn Clinical Outcomes With Delayed Bathing. AWHON.

Bergstrom A, Okong $\mathrm{P}$ and Arvdson RAB. 2007. Immediate maternal thermal respons to skin to skin care of newborn. Acta Paediatr., 96(5):655-8.

Chamberlain J, McCarty S, Sorce J, Lesman B, Schmidt S and Meyrick E., at al. 2019. Impact on delayed newborn bathing on exclusive breastfeeding rates, glucose and temperature stability, and weight loss. J Neonatal Nurs, 25(2):74-77. https://doi.org/10.1016/j.jnn.2018.11.001.

Classen and Kellie. Effect of timing of the first bath on a healthy newborn's temperature. J Obstetric Gynecologic Neonatal Nurs, 48(3): S148 - S149.

Duygu G, Sinem YC, Selda AB and Yildiz P. 2019. First bathing time of newborn infants after birth: A comparative analysis. J Specialists Pediatric Nurs, 24(2).

https://doi.org/10.1111/jspn.12239.

Edraki M, Paran M, Montaseri S, Razavi Nejad M and Montaseri Z. 2014. Comparing the effects of swaddled and conventional bathing methods on body temperature and crying duration in premature infants: a randomized clinical trial. J Caring Sci. 13(2):83-91.

Elabbassi EB, Bach V, Makki M, Delanaud S, Telliez F, Leke A, et al. 2001. Assessment of dryheat exchanges in newborns: influence of body position andclothing in SIDS. J Appl Physiol. 
Farhana SD, Khondoker MH, Azim MA and Moinul H. 2013. Isolation, characterization and determination of antimicrobial properties of lactic acid bacteria from human milk. Jordan J Biol Sci, 6(2): 111- 116.

Fraser DM and Cooper MA. 2009. Text Book Midwifery Myles. Ed 14. Jakarta: EGC.

Freitas P, Munhoz MMB, Costa P and Kimura AF. 2018. Effect of two immersion bathing techniques on the axillary temperature of preterm newborns: a pilot study. Texto Contexto Enferm, 2018; 27(1): e0580016.

Gözen D,_Çaka SY,_Beşirik SA and Perk, Y. 2019._First bathing time of newborn infants after birth: A comparative analysis. $J$ Spec Pediatr Nurs._24:12239._https://doi.org/10.1111/jspn.12239.

Haycock GB, Schwartz GJ and Wisotsky DH. 1978. Geometric method for measuring body surface area: A height-weight formula validated in infants, children, and adults. J Pediatr, 93:62-6.

Heinig MJ. 2001. Host defense benefit of breatfeeding for the infant, effect of breastfeeding duration and exclusivity. Pediatr Clin North Am, 48:105-123.

Johnson R and Taylor W. 2005. Buku Ajar Praktik Kebidanan. Editor bahasa Indonesia: Kurnianingsih S, Ester M. Jakarta; EGC, Hal.29-45.

Khaled MS and Mohammad BAZ. 2019. Thermal manipulation during broiler chicken embryogenesis modulates the splenic cytokines’ mrna expression. Jordan J Biol Sci., 12(5): 595 - 601.

Karen EV and Rita SB. 2000. The effect of timing of initial bath on newborn's temperature. J Obstetric Gynecologic Neonatatal Nurs., 29(1): 27-32. DOI: https://doi.org/10.1111/j.1552-6909.2000.tb02753.x.

Karlsson H. 1996. Skin to skin care: heat balance. Sweden: Archives if disease in childhood, 75(1): F130-F132.

Kliegman RM. 2012. Janin dan bayi neonatus. In: Wahab AS (Ed). Ilmu Kesehatan Anak Nelson. EGC, Jakarta, pp. 535-541.

Girjesh K and Shefali S. 2019. Effect of Temperature Constraints on Morphological and Cytogenetical Attributes in Cluster bean [Cyamopsis tetragonoloba (L.) Taub.]. Jordan J Biol Sci., 12(2): $229-235$.

Lubkowska A, Szymański S, Chudecka M. 2019. Surface body temperature of full-term healthy newborns immediately after birth-Pilot Study. Int J Env Res Pub Health, 16(1):1312. Available from: http://dx.doi.org/10.3390/ijerph16081312.

Lund C. 2014. Bathing and beyond; new data to guide newborn skin care. UOSF

Lund, C. 2016. Bathing and beyond, advances in neonatal care.,16(1) : S13-S20, doi: 10.1097/ANC.0000000000000336.
McHugh MK. 2008. Transisi fisiologis ke kehidupan ekstrauteri. In: Varney H, Kriebs JM and Gegor CL (Eds). Buku Ajar Asuhan Kebidanan. Ed 4. EGC, Jakarta, pp.878-888.

Morton, Sarah U and Dara Brodsky. 2016. Fetal physiology and the transition to extrauterine life. Clinics in Perinatology., 43(3): 395-407. doi:10.1016/j.clp.2016.04.001

Moore ER, Anderson GC, Bergman N and Dowswell T. 2012. Early skin-to-skin contact for mothers and their healthy newborn infants (Review). The Cochrane Library., 1(5). Diunduh dari: http:// www. thecochranelibrary.com.

Namnabati M, Zamanzadeh V, Valizadeh L, Tazakori Z and Nyqvist KH. 2017. Theory of infants' transition management from the neonatal intensive care unit to home: a qualitative study. Int J Pediatr, 5(1):4151-62. DOI:10.22038/ijp.2016.7887.

OLCHC. 2015. Guideline of bathing an infant. OLCHC.

Perlman J and Kjaer K. 2016. Neonatal and maternal temperature regulation during and after delivery. Journals.lww.com/anesthesia-analgesia, 123(1):168-72. DOI: 10.1213/ANE.0000000000001256.

Puspita IR, Suradi R and Munasir Z. 2007. Insidens dan faktor risiko hipotermia akibat memandikan bayi baru lahir cukup bulan. Sari Pediatri, 8(2)

Sastroasmoro S. 2011. Dasar-Dasar Metodologi Penelitian Klinis. CV Sagung seto, Jakarta, pp.31-63.

Sherwood L. 2012. Fisiologi Manusia, sixth ed. EGC, Jakarta.

Sukesi A, Setiyani A and Esyuananik. 2016. Modul Bahan Ajar Cetak Kebidanan; Praktikum Asuhan Kebidanan Neonatus, Bayi Balita dan Anak Prasekolah. Kemenkes RI.

Susan W, William KM, Leigh AAN, Phil M and Laurie T. 2019. Effects of delayed newborn bathing on breastfeeding, hypothermia, and hypoglycemia. J Obstetric Gynecologic Neonatal Nurs, 10(1): 1016/j.jogn.

Thilo EH and Rosenberg AA. 2011. The newborn infant. In: Hay WW, Levin JM, Sondheimer JM and Deterding RR (Eds). Current Diagnosis \& Treatment: Pediatrics. 21th ed. Lange, USA, pp.30-31.

Turney J, Lowther, Pyka J, Mollon D and Fields W. 2019. Delayed newborn first bath and exclusive breastfeeding rates. AWHONN; doi: 10.1016/j.nwh.2018.12(3).

WHO. 2013. WHO Recommendation on postnatal care of the mother and newborn. WHO.

WHO. 2017. WHO Recommendation on newborn health: guidelines approve by The WHO guidelines review committee. Geneva: World Health Organization; (WHO/MCA/17.07). License: CC-BY-NC-SA 3.0 IGO.

WNHS. 2018. NEO thermoregulation. Clinical practice guideline 